\title{
Pseudomonas aeruginosa induced acute emphysema through bacterial secretion in mice
}

Yajie $\mathrm{Zhu}^{1}$, and Shuming $\operatorname{Pan}^{1} *$

${ }^{1}$ Department of Emergency Medicine, Xinhua Hospital, Shanghai Jiao Tong University School of Medicine, Shanghai, 200092, China

*Correspondence : Shu-ming Pan, Tel: +8602125078999, Fax: +8602165030840, E-mail: panshuming@xinhuamed.com.cn

\section{Authors' Contributions}

Yajie Zhu contributed to the original findings and study conception, data analysis, and manuscript preparation. Shuming Pan contributed to the study conception, data analysis, and manuscript preparation. Shuming Pan was responsible for the study supervision. Both authors critically reviewed the manuscript for important intellectual content and read and approved the final manuscript.

\section{Declaration of interests}

The authors declare no conflicts of interest in this work.

\section{Funding}

National Natural Science Foundation of China. NSFC NO.81772111. 


\begin{abstract}
Pulmonary emphysema is the major pathological feature of chronic obstructive pulmonary disease (COPD). Although the pathogenesis of emphysema is still not completely understood, but until now a bacterial cause has not really been considered. Recently, we found that the secretion from Pseudomonas aeruginosa could cause severe lung emphysema in mice rapidly. Since the bacterium is ubiquitous and secrets proteases, we hypothesized that direct P. aeruginosa airway infection would have a similar effect. To address this issue, we applied a unilateral lung injury model. First, we observed the dynamic pathophysiology change of acute emphysema. P. aeruginosa secretion was extracted and instilled intratracheally into the left lungs of C57BL/6 and $\mathrm{C} 3 \mathrm{H} / \mathrm{HeJ}$ mice, while the right lungs were saved as self-control. Alveolar diameter and lung compliance were measured. Later, we tested the effect of P. aeruginosa inoculation in normal C57BL/6 mice, immunosuppressed C57BL/6 mice, and C3H/HeJ (TLR4 deficient) mice. P. aeruginosa secretion extract caused acute panacinar emphysema and decreased dynamic lung compliance. Different types of emphysema are transformable. However, the P. aeruginosa infection could only elicit emphysema in immunosuppressed $\mathrm{C} 57 \mathrm{BL} / 6$ mice and $\mathrm{C} 3 \mathrm{H} / \mathrm{HeJ}$ mice, indicating that normal immunity is essential to protect the hosts from emphysema. Emphysema induced by P. aeruginosa in mice recapitulates all the main features of human emphysema and COPD. Our finding filled a major gap in COPD pathogenesis. We believe P. aeruginosa is the underlying cause of COPD.
\end{abstract}

Key words: Emphysema, acute COPD, pathogenesis, unilateral lung injury, Pseudomonas aeruginosa 


\section{Introduction}

Chronic obstructive pulmonary disease (COPD) is the third leading cause of death globally, characterized by irreversible obstruction of the small airways (bronchiolitis) and destruction of lung parenchyma (emphysema), which lead to air trapping, dyspnea, and even respiratory failure[1]. The pathogenesis of COPD is largely attributed to cigarette smoking induced chronic lung inflammation; however, it could not explain the fact that many COPD patients did not smoke [2], and only $40 \%$ of heavy smokers developed emphysema[3]. Current animal models established by passive tobacco smoking or elastase instillation poorly reproduce the main features of human COPD[4]. Accumulating evidence suggests a better understanding of the disease mechanism is needed.

Pseudomonas aeruginosa is a gram-negative, aerobic, opportunistic bacterium with a wide distribution. In the lung, $P$. aeruginosa is known to prevalent among immunocompromised hosts, causing cystic fibrosis, bronchiectasis and nosocomial pneumonia [5]. P. aeruginosa would colonize in the lung after COPD formation and contribute to the acute exacerbation [6, 7]. It can be isolated from $4-15 \%$ of adults with COPD, a number probably greatly underestimated due to this organism's unique ability to form biofilms, making it difficult to detect[8]. P. aeruginosa expresses a variety of virulence factors including endotoxin, exotoxin, elastase, alkaline proteases and hemolysins [9]. The proteases can disrupt epithelial cell tight junctions, cleave collagen, IgG, IgA, complement, and degrade surfactant proteins, causing harm to the lung[10]. However, the manifestation of $P$. aeruginosa pneumonia reported is nonspecific compared with other bacteria[11].

Recently, we discovered accidently that distinguished from Klebsiella pneumoniae, Staphylococcus aureus, Escherichia coli and Proteus mirabilis, the secretion of $P$. aeruginosa could induce severe pulmonary emphysema in murine rapidly. Surprised by this finding, for bacterial factors were never reported to be an initiator in emphysema 
development $[4,12]$, we hypothesized that this phenomenon was caused by the proteases secreted by $P$. aeruginosa. Thus, theoretically, P. aeruginosa infection shall lead to acute emphysema too. To address the issue, a unilateral lung instillation model of normal C57BL/6, immunosuppressed $\mathrm{C} 57 \mathrm{BL} / 6$ and $\mathrm{C} 3 \mathrm{H} / \mathrm{HeJ}$ mice were used. We observed the dynamic pathology evolution and physiology changes in this study.

\section{Materials and Methods}

\section{Ethical statement}

All experiments referring to the use of animals in this study were approved by the Institutional Animal Care and Use Committee of Shanghai Xinhua Hospital affiliated to Shanghai Jiao Tong University School of Medicine (XHEC-F-2018-047).

\section{Mice}

C57BL/6 mice (10 weeks old) were purchased from Shanghai Sippr-BK laboratory animal Co. Ltd; C3H/HeJ mice (10weeks old) were purchased from Shanghai SLAC laboratory animal Co. Ltd. All mice were accommodated at the Model Animal Research Center of Xinhua Hospital in a specific pathogen-free animal facility under constant temperature and humidity, with sufficient qualified food and water for 1 to 2 weeks before use.

\section{Isolation and identification of $P$. aeruginosa}

P. aeruginosa strain was originally separated from sputum, confirmed through mass spectrometry and the strain kept at the bacteriology lab of Xinhua Hospital. To observe the morphology and culture characteristics, the purified strain was streaked on Sheep blood agar plates (Yi Hua, Shanghai) and nutrient agar plates (Comagal, Shanghai) and incubated at $37^{\circ} \mathrm{C}$ for $24-36$ hours.

\section{Bacterial secretion extraction and identification}


$1 \times 10^{6} \mathrm{CFU} P$. aeruginosa were streaked on sheep blood agar plate and incubated at $37^{\circ} \mathrm{C}$ for $24-48$ hours. To harvest the P. aeruginosa secretion, all colonies on the blood agar plate were scratched down, collected, and dissolved in 5ml PBS then centrifuged at $3000 \mathrm{rcm}$ for 10 minutes. The supernatant was collected, filtered through a $0.22 \mu \mathrm{m}$ PES membrane filter unit (Millex, Merck), and stored at $-20 \square$ for later use. The quantification of the supernatant protein concentration was carried through BCA protein assay (Beyotime, China). Protein types in the secretion were identified by protein mass spectrometry. Briefly, the secretion extract went through enzymatic hydrolysis and was analyzed by a Q-Exactive mass spectrometer (Thermo, USA). Proteome Discoverer (v.2.4) was used to search all of the raw data thoroughly against the protein database (UniProt_Pseudomonas aeruginosa). Names and abundances of proteins were acquired as the result.

\section{Live bacteria preparation}

P. aeruginosa was streaked on sheep blood agar plate and incubated at $37^{\circ} \mathrm{C}$ for 8 hours. A proper number of colonies were inoculated in sterile PBS and the turbidity was adjusted to $2 \mathrm{McF}$ arland standards (MCF), which equals $6 \times 10^{8} \mathrm{CFU} / \mathrm{ml}$, by the standard procedure for later use.

\section{Immunosuppression model}

The immunosuppressed model of C57BL/6 mice was established by intraperitoneal administration of dexamethasone sodium phosphate (DEX) $25 \mathrm{mg} / \mathrm{kg}$ per day for a consecutive 5 days referring to the method described by Rasmussen KR and colleges[13]. Control mice received the same dosage of normal saline intraperitoneally. The immunosuppression status was confirmed on the sixth day by evaluating the organ-to-body weight ratios of the spleen (relative spleen weight)[14]. C3H/HeJ mice were used directly as immunodeficient mice for their lack of Toll-like receptor 4.

\section{Unilateral lung instillation}


In the unilateral lung injury mice model, the left lung was set as the instillation side and the right lung was set as the control side. Mice were anesthetized through injecting $1 \%$ pentobarbital sodium $(50 \mathrm{mg} / \mathrm{Kg})$ intraperitoneally and put to a proper supine position. The anterior cervical hair was removed and the skin disinfected with $75 \%$ ethanol. To expose the trachea, a small longitudinal incision was made and endotracheal intubation performed between the second to fourth cricoid cartilage using a 24G intravenous indwelling catheter (Introcan, BRAUN). The $19 \mathrm{~mm}$ long $24 \mathrm{G}$ cannula was then inserted gently into the left main bronchus. A volume of 30ul P. aeruginosa secretion extract was delivered into the left lung of each mouse using microliter syringes (Gaoge, Shanghai). Different dosage of live bacteria was inoculated through the same method. After the intratracheal instillation, mice were put back to the mouse cage with a thermal pad underneath, resting in the left recumbent position until full recovery from anesthesia.

\section{Measurement of lung compliance}

Dynamic lung compliances were measured 7 days after unilateral lung instillation of bacterial secretion. The main surgery procedures were the same as above. A $22 \mathrm{G}$ intravenous indwelling catheter (Introcan, BRAUN) was used for endotracheal intubation. After exposure of the main trachea, $5 \mathrm{~mm}$ of the catheter tip was inserted into the main trachea and a ventilator for rodents (Vent Jr, Kent) was connected to the catheter. Target tidal volume range between $0.2-0.5 \mathrm{ml}$ was set and the corresponding peak pressure was recorded each $(R R=100 \mathrm{bpm})$. Lung dynamic compliance $\left(\mathrm{C}_{\mathrm{dyn}}\right)$ was calculated through linear regression by GraphPad Prism 8 software.

\section{Lung histopathology}

Mice were sacrificed at different time points set. The lung was inflated with $4 \%$ paraformaldehyde fixative under constant pressure of 15 to $25 \mathrm{~cm} \mathrm{H}_{2} \mathrm{O}$ via the trachea and the trachea then tied off. Lung and heart were harvested en bloc and submerged in 
fixative for approximately 24 hours before the heart was removed and lung was embedded in paraffin blocks for tissue sections $(5 \mu \mathrm{m})$. Hematoxylin and eosin staining were performed subsequently. Slides were scanned (PANNORAMIC, 3DHISTECH), reviewed and evaluated.

\section{Alveolar mean linear intercept $(\mathbf{L m})$}

Air space enlargement was measured using the Short \& Hennig method, 1967. Briefly, HE stained sections were scanned and reviewed in Caseviewer software. 10 random fields of each right lung and left lung were randomly selected. Equally crossed two lines (both 1000um) were drawn on the scope. The mean linear intercept Lm was then calculated: $\mathrm{Lm}=\mathrm{N} * \mathrm{~L} / \mathrm{m}$ [15]. In this case, $\mathrm{Lm}=2 * 10^{4} / \mathrm{m}(\mu \mathrm{m})$. To better measure how much the left lung air space has enlarged compare to the right lung, Lm Ratio was further calculated, Lm Ratio=Lm (left lung)/ Lm (right lung).

\section{Statistics}

The data were expressed as the mean \pm standard error of mean. Statistical analysis was performed in the GraphPad Prism 8 software. Pair-wise comparisons were made using t-tests, whereas multiple comparisons were made using one-way analysis of variance (ANOVA) test. The confidence interval was set at $95 \%$ for all tests. Groups of three or four animals were used in each experiment.

\section{Results}

\section{Identification of $P$. aeruginosa}

P. aeruginosa was originally isolated and purified from a clinical sputum sample and confirmed through mass spectrometry. The strain exhibited typical P. aeruginosa characteristics including strong ginger odor, green metallic sheen, and beta-hemolytic on blood agar with blue-green pigment producing on nutrient agar (Figure 1). The $P$. aeruginosa secretion extract was translucid, light green colored with a strong ginger 
odor. The total protein concentration was $0.35 \mathrm{mg} / \mathrm{ml}$.

\section{P. aeruginosa secretion causes different types of emphysema in different mice}

Two days after unilateral pulmonary instillation of $P$. aeruginosa secretion, severe parenchymal destruction can be seen, characterized by prominent panacinar emphysema with acute inflammation in the left lung of both C57BL/6 mice and $\mathrm{C} 3 \mathrm{H} / \mathrm{HeJ}$ mice while the right lung remained mostly unharmed (Figure 2). Neutrophil infiltration and erythrocyte diapedesis appeared in both mice group. $\mathrm{C} 3 \mathrm{H} / \mathrm{HeJ}$ mice had much lighter inflammation response since they are TLR4 deficient and thus blunt in pathogen sensation. Lm Ratio indicates the alveolar of the left lung had enlarged more than three times in C57BL/6 mice, and two times in C3H/HeJ mice (Figure 3B).

Seven days after the instillation, inflammation faded and panacinar emphysema was well developed and maintained in $\mathrm{C} 3 \mathrm{H} / \mathrm{HeJ}$ mice without fibrosis. While interestingly in C57BL/6 mice, the panacinar emphysema had changed to distal emphysema with most of the left lung consolidated. Fibrosis is obvious, inflammation cells can be seen excreting from alveolars and bronchus. To decide if the panacinar emphysema would recur after inflammation resolution, we observed C57BL/6 mice models to three weeks after instillation. Surprisingly, Large apical and subpleural bullae appeared. Histopathology shows all four types of emphysema (centriacinar, panacinar, distal acinar and irregular) coexisting in the left lung and compensatory emphysema developed in the right lung after 21 days (Figure 2B).

During the above modeling process, C57BL/6 mice underwent dyspnea, huddle, weight loss and scaphoid abdomen while $\mathrm{C} 3 \mathrm{H} / \mathrm{HeJ}$ mice showed no obvious symptoms or weight loss (Figure 3C).

\section{P. aeruginosa secrets heat-labile proteases}

After heated for $80^{\circ} \mathrm{C}, 30 \mathrm{mins}$, the bacterial secretion lost the ability to cause emphysema but still induced neutrophil infiltration (data not shown), indicating 
different components are responsible for alveolar destruction and inflammation. Protein mass spectrometry confirmed the protein types in the secretion include a high abundance of metal-dependent hydrolase, urocanate hydratase and other enzymes (supplementary material), suggesting the emphysema was caused by heat-labile proteases.

\section{Dynamic lung compliance decreased after instillation}

Seven days after unilateral lung instillation of bacterial secretion, $\mathrm{C}_{\mathrm{dyn}}$ of C57BL/6 mice decreased from 0.041 to $0.031 \mathrm{ml} / \mathrm{cmH}_{2} \mathrm{O}$ while $\mathrm{C}_{\text {dyn }}$ of $\mathrm{C} 3 \mathrm{H} / \mathrm{HeJ}$ mice decreased from 0.045 to $0.036 \mathrm{ml} / \mathrm{cmH}_{2} \mathrm{O}$. Peak pressure and targeted tidal volume were not well linearly correlated as they used to (Figure 3D).

\section{P. aeruginosa infection induces emphysema in immunocompromised but not immunocompetent mice}

Different bacteria dosages, infection time and other conditions in normal C57BL/6 mice were tested, but none of the mice showed noteworthy emphysema $(n \geq 10)$. A representative case is the mouse was attacked with $15 \mu$ of 5 MCF P. aeruginosa, which formed a prominent abscess full of $P$. aeruginosa bacteria at the apex of the left lung after 24 hours, but it only caused bronchiectasis-like pathology change in a few areas (Figure 4). Whereas, all $\mathrm{C} 3 \mathrm{H} / \mathrm{HeJ}$ mice developed homogenous emphysema after live bacteria instillation $(\mathrm{n}=7) .15 \mu \mathrm{l}$ of $0.5 \mathrm{MCF}$ P. aeruginosa-1/10 of the dosage used in C57BL/6 mice-was able to cause obvious centriacinar emphysema in $\mathrm{C} 3 \mathrm{H} / \mathrm{HeJ}$. This result reveals that emphysema induced by $P$. aeruginosa is not dosage-dependent.

In order to decide if the induced emphysema is related to species or immunity differences, we used dexamethasone to suppress the immune reaction of C57BL/6 mice, this immunosuppressed C57BL/6mice, together with $\mathrm{C} 3 \mathrm{H} / \mathrm{HeJ}$ mice, and normal

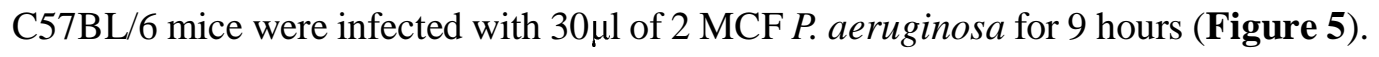
Centriacinar pulmonary emphysema occurred in both immunosuppressed C57BL/6 
mice and $\mathrm{C} 3 \mathrm{H} / \mathrm{HeJ}$ mice but not in normal C57BL/6 mice. A comparison of the $\mathrm{Lm}$ Ratios between different groups shows that $P$. aeruginosa infection had caused airspace enlargement in two immunocompromised mice groups but alveolar collapse and lung compression in normal C57BL/6 mice group.

\section{Discussion}

In this study, we applied a unilateral lung injury model and found the secretion of $P$. aeruginosa could cause acute emphysema in mice. Utilizing live P. aeruginosa bacteria, we successfully induced emphysema in both immunosuppressed C57BL/6 and $\mathrm{C} 3 \mathrm{H} / \mathrm{HeJ}$ mice, but not in any C57BL/6 mice with normal immunity. Our findings show that the pathogenesis of COPD can be naturally acute and cigarette smoking irrelevant. Chronic inhalation of noxious particles could have impaired immune function and contributed to COPD formation by creating a circumstance that favors $P$. aeruginosa to survive and thrive $[16,17]$.

Many researches have pointed out $\mathrm{P}$. aeruginosa is closely related to $\operatorname{COPD}[18,19] . P$. aeruginosa is a nonfastidious bacterium that can proliferate in distilled water and is one of the strongest antibiotic-resistant bacteria[10]. The secretion of $P$. aeruginosa is a mixture of metal-dependent hydrolase, enzymes, and bacterial endo/exotoxins which elicits strong inflammation in normal mice. Interestingly, it seems the neutrophils played a positive role in preventing emphysema formation. Immunosuppressed C57BL/6 as well as TLR4 deficient $\mathrm{C} 3 \mathrm{H} / \mathrm{HeJ}$ mice who had lighter inflammatory response and neutrophils infiltration than C57BL/6 mice, exhibited more severe airspace dilation.

Protease-antiprotease imbalance as a result of cigarette smoking induced chronic inflammation is the potential mechanism of COPD, based on the observation that patients with a genetic deficiency of $\alpha 1$-anti-trypsin have a predisposition to develop emphysema[3]. Emphysema caused by lung instillation of porcine pancreatic elastase 
as a widely used disease model supported this theory[20]. Many studies found elevated matrix metalloproteinases (MMPs) concentration and increased elastin degradation in COPD patients [21-23]. Neutrophil or macrophage elastases were held culprit[24]. But it seems that the proteolytic enzymes secreted by various bacteria had not been taken into account. Proteases secretion is a common feature in P. aeruginosa and other bacteria[25], however, it didn't occur to us before that the excessive elastase may come from an outer pathogen rather than our own neutrophils.

Whereas, most researches conducted used animals with normal immunity. $\alpha 1$-anti-trypsin secreted by local macrophages and liver is a major inhibitor of proteases normally presented in serum and tissue fluids. If the immunity is unimpaired, proper inflammation response could increase $\alpha 1$-anti-trypsin level to eliminate the destructive effects caused by bacteria proteases[12]. Our research supported this concept by demonstrating that $\mathrm{P}$. aeruginosa infection only caused limited bronchiectasis in normal mice. But competent immunity does not guarantee a waiver from emphysema. Excessive proteases stimulation proved effective in all mice regardless of background[26]. It is reasonable to conclude that emphysema formation is mainly determined by bacterial proteases dosage and secondly influenced by immunity status.

Centriacinar and panacinar emphysema are most commonly found in COPD patients and regarded as distinct entities. Centriacinar emphysema is closely associated with tobacco smoking while panacinar emphysema is usually associated with $\alpha 1$-anti-trypsin deficiency[27, 28]. However, we found the subtypes of emphysema are related and transformable to each other. In $\mathrm{C} 3 \mathrm{H} / \mathrm{HeJ}$ mice, the acute emphysema transited to stable irreversible panacinar emphysema while in normal C57BL/6 mice, it went through dynamic change interweaved with inflammation and developed to other subtypes of emphysema as well as bullae. At the same time, fibrosis in the lung has nothing to do with emphysema but is determined by the immune reaction of the hosts. If the stimulus is not persistent, fibrosis would gradually disperse and emphysema would 
recur.

The difference of air space volume is hard to detect since lung tissue has a nature of instability. In our study, even lungs were carefully inflated with fixative under constant pressure, the many steps in the histopathology preparation process still impacted the final pressure, which can be seen from the variation of alveolar diameters of control lung between different mouse. We solved this difficulty by utilizing the unilateral instillation model which were readily used in a few studies[29, 30]. A mouse model of unilateral injury can provide valuable self-control, eliminate systemic influence, and reduce the use of lab animals. By ensuring the pressure is equal within the lung, minor changes could be detected and compared. The Lm Ratio of left to right lung further revealed clearly how much the airspace has enlarged or compressed.

However, a unilateral lung injury model is not perfect. Sometimes contamination of the control lung caused by the sneeze or cough of mice is not totally avoidable, especially in bacterial infection models. Thus, the histology changes in the main bronchus of the control lung should be interpreted carefully. We tried to do more quantitative assessment of the lung structure according to standard recommendation[31], but found it is impractical when a heavy inflammation occurs (Figure 2h). Due to this reason, we had to sacrifice bacteria inoculated mice after 9 hours, before the inflammatory response makes it impossible to measure $\mathrm{Lm}$.

On the contrary to the current paradigm taking lung infection as no participant in emphysema initiation but only contribute to exacerbation, we discovered for the first time that $P$. aeruginosa caused acute emphysema through bacterial proteases in immunodeficient animals, which is in comply with its predilection to infect immunocompromised patients. Emphysema induced by P. aeruginosa in mice recapitulates all the main features of human emphysema and COPD. We believe $P$. aeruginosa is the underlying cause of COPD. In the future, strategies aimed at developing a vaccine or specialized antibiotics targeting $P$. aeruginosa may be useful 
for COPD prevention and treatment.

\section{Acknowledgements}

We would like to thank Dr. Feng Chen and Dr. Jingxian Liu (Bacteriology Lab, Xinhua Hospital) as well as Professor Yong Zhang (Department of Immunology, SJTUSM) and

Professor Min Wang (Department of Histology and Embryology, SJTUSM) for their skilled advice and assistance; 


\section{References}

[1] Rabe KF, Watz H. Chronic obstructive pulmonary disease. Lancet (London, England). 2017;389(10082):1931-40.

[2] Hogg JC. Pathophysiology of airflow limitation in chronic obstructive pulmonary disease. Lancet (London, England). 2004;364(9435):709-21.

[3] MacNee W. Pathogenesis of chronic obstructive pulmonary disease. Proceedings of the American Thoracic Society. 2005;2(4):258-66; discussion 90-1.

[4] Liang GB, He ZH. Animal models of emphysema. Chinese medical journal. 2019;132(20):2465-75.

[5] Restrepo MI, Babu BL, Reyes LF, Chalmers JD, Soni NJ, Sibila O, et al. Burden and risk factors for Pseudomonas aeruginosa community-acquired pneumonia: a multinational point prevalence study of hospitalised patients. Eur Respir J. 2018;52(2). [6] Sethi S, Murphy TF. Infection in the pathogenesis and course of chronic obstructive pulmonary disease. N Engl J Med. 2008;359(22):2355-65.

[7] Eklöf J, Sørensen R, Ingebrigtsen TS, Sivapalan P, Achir I, Boel JB, et al. Pseudomonas aeruginosa and risk of death and exacerbations in patients with chronic obstructive pulmonary disease: an observational cohort study of 22053 patients. Clinical microbiology and infection : the official publication of the European Society of Clinical Microbiology and Infectious Diseases. 2020;26(2):227-34.

[8] Murphy TF, Brauer AL, Eschberger K, Lobbins P, Grove L, Cai X, et al. Pseudomonas aeruginosa in chronic obstructive pulmonary disease. Am J Respir Crit Care Med. 2008;177(8):853-60.

[9] Li J, Ramezanpour M, Fong SA, Cooksley C, Murphy J, Suzuki M, et al. Pseudomonas aeruginosa Exoprotein-Induced Barrier Disruption Correlates With Elastase Activity and Marks Chronic Rhinosinusitis Severity. Frontiers in cellular and infection microbiology. 2019;9:38.

[10]Sadikot RT, Blackwell TS, Christman JW, Prince AS. Pathogen-host interactions in Pseudomonas aeruginosa pneumonia. Am J Respir Crit Care Med. 
2005;171(11):1209-23.

[11]Fujitani S, Sun HY, Yu VL, Weingarten JA. Pneumonia due to Pseudomonas aeruginosa: part I: epidemiology, clinical diagnosis, and source. Chest. 2011;139(4):909-19.

[12]Aster VKAAJ. Robbins Basic Pathology. 10th Edition ed2017 28th March 2017. $952 \mathrm{p}$.

[13]Rasmussen KR, Healey MC. Experimental Cryptosporidium parvum infections in immunosuppressed adult mice. Infect Immun. 1992;60(4):1648-52.

[14]Manente FA, Quinello C, Ferreira LS, de Andrade CR, Jellmayer JA, Portuondo DL, et al. Experimental sporotrichosis in a cyclophosphamide-induced immunosuppressed mice model. Medical mycology. 2018;56(6):711-22.

[15]Dunnill MS. Quantitative methods in the study of pulmonary pathology. Thorax. 1962;17(4):320-28.

[16]Faure K, Sawa T, Ajayi T, Fujimoto J, Moriyama K, Shime N, et al. TLR4 signaling is essential for survival in acute lung injury induced by virulent Pseudomonas aeruginosa secreting type III secretory toxins. Respiratory research. 2004;5(1):1.

[17]Drannik AG, Pouladi MA, Robbins CS, Goncharova SI, Kianpour S, Stämpfli MR. Impact of cigarette smoke on clearance and inflammation after Pseudomonas aeruginosa infection. Am J Respir Crit Care Med. 2004;170(11):1164-71.

[18]Martínez-Solano L, Macia MD, Fajardo A, Oliver A, Martinez JL. Chronic Pseudomonas aeruginosa infection in chronic obstructive pulmonary disease. Clin Infect Dis. 2008;47(12):1526-33.

[19]Boutou AK, Raste Y, Reid J, Alshafi K, Polkey MI, Hopkinson NS. Does a single Pseudomonas aeruginosa isolation predict COPD mortality? Eur Respir J. 2014;44(3):794-7.

[20]Antunes MA, Rocco PR. Elastase-induced pulmonary emphysema: insights from experimental models. Anais da Academia Brasileira de Ciencias. 2011;83(4):1385-96. [21]Chaudhuri R, McSharry C, Brady J, Donnelly I, Grierson C, McGuinness S, et al. 
Sputum matrix metalloproteinase-12 in patients with chronic obstructive pulmonary disease and asthma: relationship to disease severity. J Allergy Clin Immunol. 2012;129(3):655-63.e8.

[22]Maclay JD, McAllister DA, Rabinovich R, Haq I, Maxwell S, Hartland S, et al. Systemic elastin degradation in chronic obstructive pulmonary disease. Thorax. 2012;67(7):606-12.

[23]Wells JM, Parker MM, Oster RA, Bowler RP, Dransfield MT, Bhatt SP, et al. Elevated circulating MMP-9 is linked to increased COPD exacerbation risk in SPIROMICS and COPDGene. JCI Insight. 2018;3(22).

[24]Tanner L, Single AB. Animal Models Reflecting Chronic Obstructive Pulmonary Disease and Related Respiratory Disorders: Translating Pre-Clinical Data into Clinical Relevance. Journal of innate immunity. 2020;12(3):203-25.

[25]Galloway DR. Pseudomonas aeruginosa elastase and elastolysis revisited: recent developments. Molecular microbiology. 1991;5(10):2315-21.

[26]Mahadeva R, Shapiro SD. Chronic obstructive pulmonary disease * 3: Experimental animal models of pulmonary emphysema. Thorax. 2002;57(10):908-14. [27]Finkelstein R, Ma HD, Ghezzo H, Whittaker K, Fraser RS, Cosio MG. Morphometry of small airways in smokers and its relationship to emphysema type and hyperresponsiveness. Am J Respir Crit Care Med. 1995;152(1):267-76.

[28]Kim WD, Eidelman DH, Izquierdo JL, Ghezzo H, Saetta MP, Cosio MG. Centrilobular and panlobular emphysema in smokers. Two distinct morphologic and functional entities. Am Rev Respir Dis. 1991;144(6):1385-90.

[29]Dames C, Akyüz L, Reppe K, Tabeling C, Dietert K, Kershaw O, et al. Miniaturized bronchoscopy enables unilateral investigation, application, and sampling in mice. Am J Respir Cell Mol Biol. 2014;51(6):730-7.

[30]Singer T, Brand V, Moehrlen U, Fehrenbach H, Purkabiri K, Ott SR, et al. Left-sided mouse intubation: description and evaluation. Experimental lung research. 2010;36(1):25-30. 
bioRxiv preprint doi: https://doi.org/10.1101/2020.09.08.287003; this version posted September 18. 2020. The copvriaht holder for this preprint (which was not certified by peer review) is the author/funder, who has granted bioRxiv a license to display the preprint in perpetuity. It is made available under aCC-BY-NC-ND 4.0 International license.

[31]Hsia CC, Hyde DM, Ochs M, Weibel ER. An official research policy statement of the American Thoracic Society/European Respiratory Society: standards for quantitative assessment of lung structure. Am J Respir Crit Care Med. 2010;181(4):394-418. 
bioRxiv preprint doi: https://doi.org/10.1101/2020.09.08.287003; this version posted September 18, 2020. The copyright holder for this preprint (which was not certified by peer review) is the author/funder, who has granted bioRxiv a license to display the preprint in perpetuity. It is made available under aCC-BY-NC-ND 4.0 International license.

\section{Figures}

A

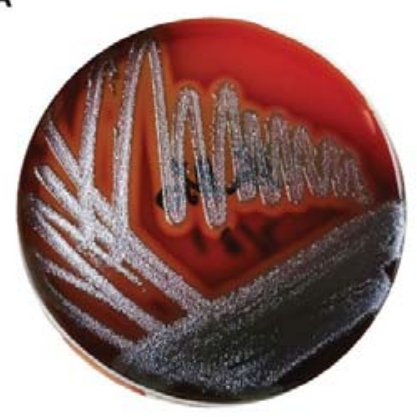

Sheep blood agar
B

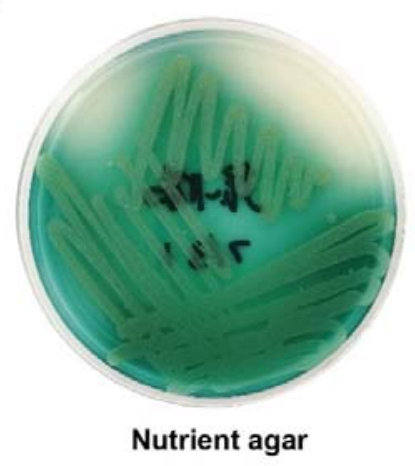

Figure 1 Culture characteristics of the $P$. aeruginosa strain. The strain exhibits typical green metallic sheen, beta-hemolysis, and produces beautiful blue-green pigment. 
A
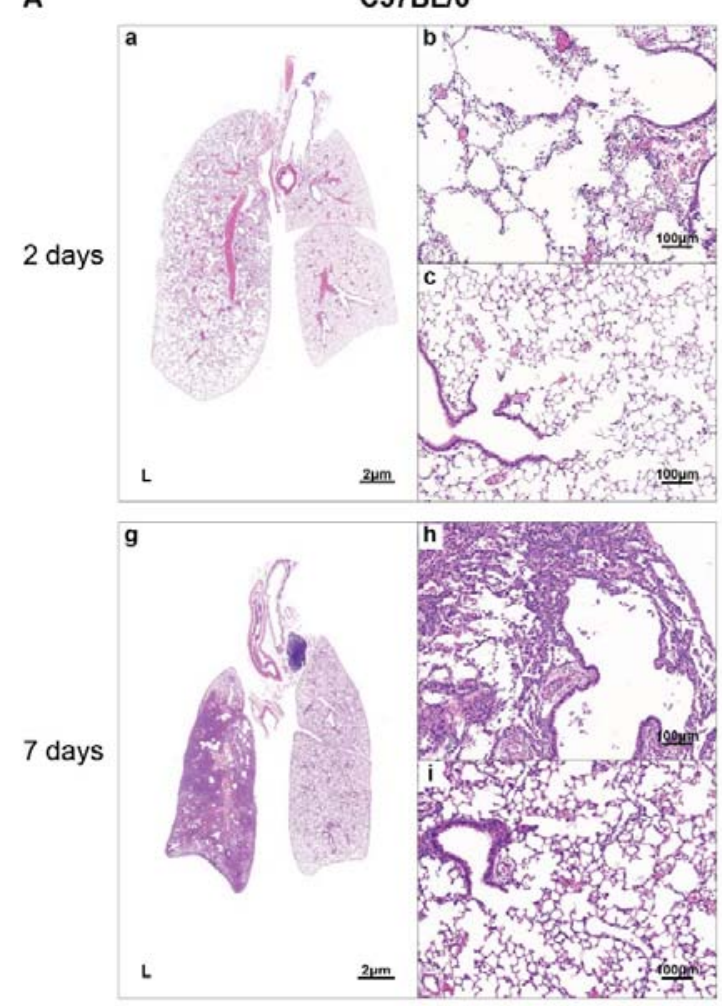

$\mathrm{C} 3 \mathrm{H} / \mathrm{HeJ}$
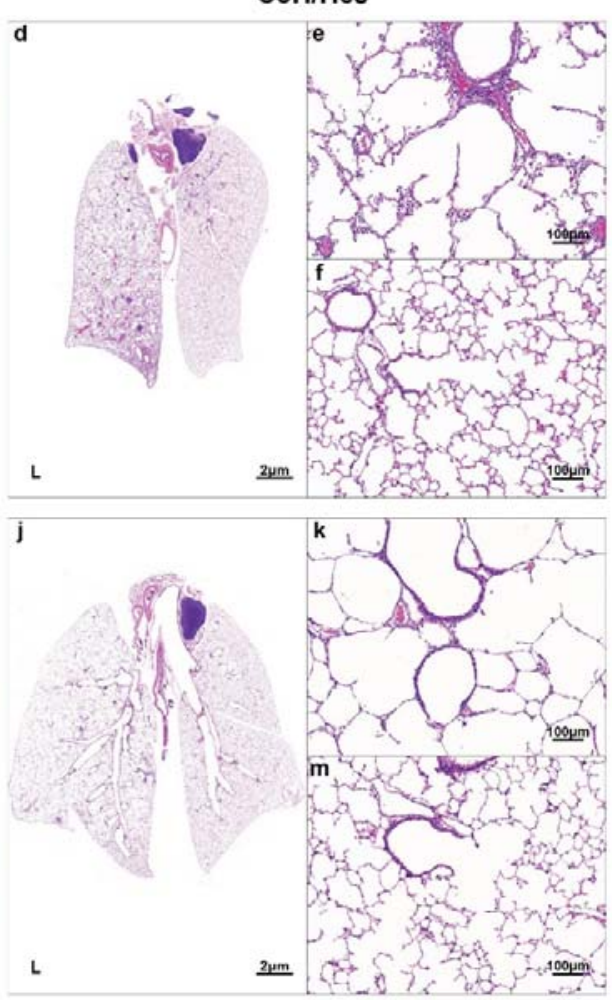

B

C57BL/6
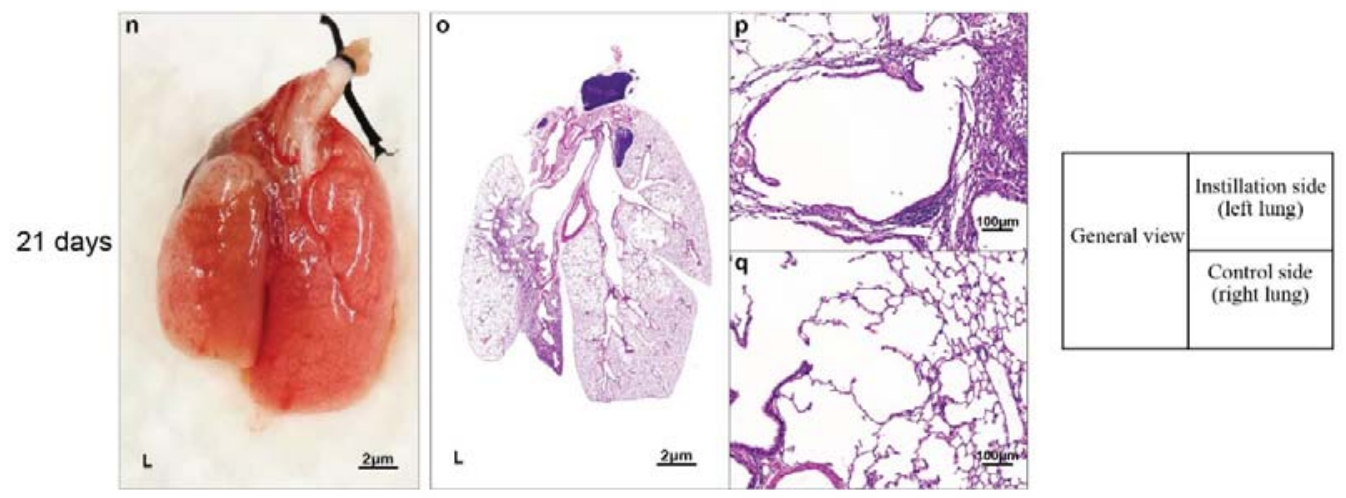

Figure 2 Unilateral pulmonary instillation of $\boldsymbol{P}$. aeruginosa secretion: Two days after instillation, acute panacinar emphysema with inflammation in the left lung of both C57BL/6 mice (b) and C3H/HeJ mice (e). Seven days after instillation, obvious fibrosis and distal emphysema formed in C57BL/6 mice (h) but not in $\mathrm{C} 3 \mathrm{H} / \mathrm{HeJ}(\mathrm{k})$. Three weeks after stimulation, C57BL/6 mice developed large apical and subpleural bullae (n). Subtypes of emphysema coexisting in the left lung (o, p) and compensatory emphysema developed in the right lung (q). All right lungs served as self-control (c, f, i, 
bioRxiv preprint doi: https://doi.org/10.1101/2020.09.08.287003; this version posted September 18, 2020. The copyright holder for this preprint (which was not certified by peer review) is the author/funder, who has granted bioRxiv a license to display the preprint in perpetuity. It is made available under aCC-BY-NC-ND 4.0 International license.

m, q); Hematoxylin and eosin (H\&E) staining; 
A

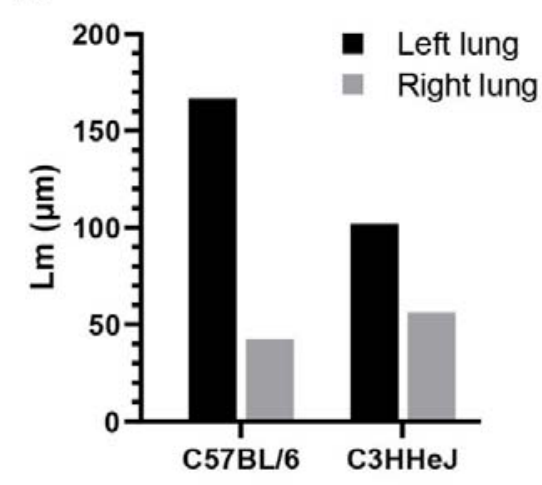

C

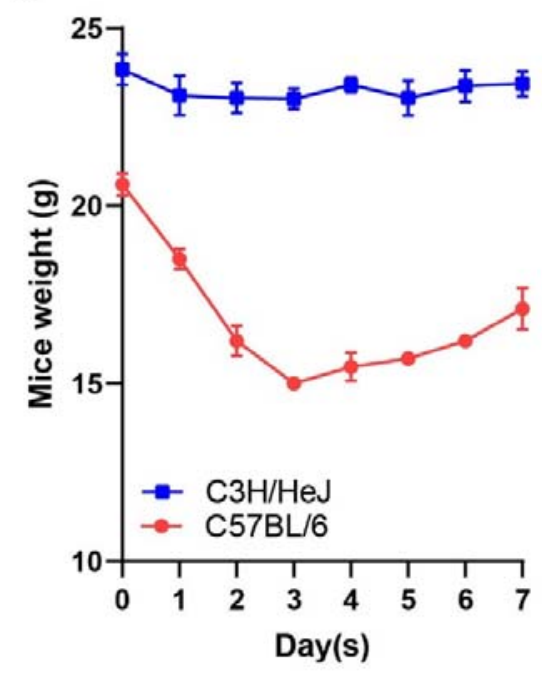

B

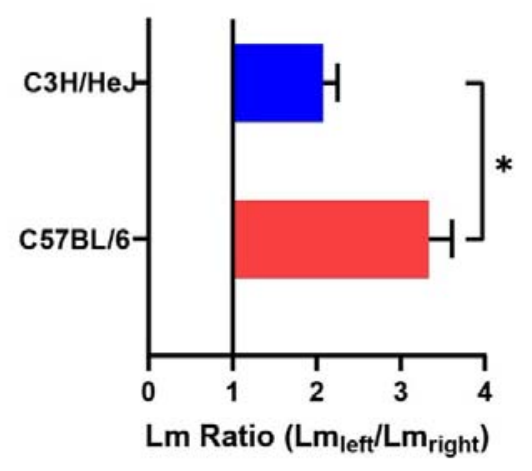

D

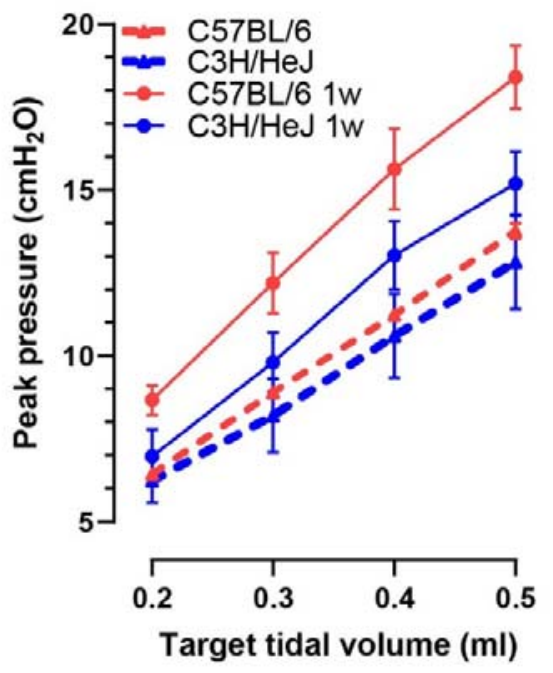

Figure 3: Lm Ratio and dynamic lung compliance: (A) Lm of the C57BL/6 mice (Figure 2-a) and the $\mathrm{C} 3 \mathrm{H} / \mathrm{HeJ}$ mice (Figure 2-d) 2 days after instillation. (B) Lm ratio indicates the alveolar of the left lung had enlarged more than three times in C57BL/6 group, and two times in $\mathrm{C} 3 \mathrm{H} / \mathrm{HeJ}$ group. (C) C57BL/6 mice endured obvious weight loss in comparison with $\mathrm{C} 3 \mathrm{H} / \mathrm{HeJ}$ mice. (D) Dynamic lung compliance of both mice decreased 7 days after modeling. The data represent the mean \pm SEM of three animals. $* \mathrm{P}<.05 ; * * \mathrm{P}<.01 ; * * * \mathrm{P}<.001 ;$ 


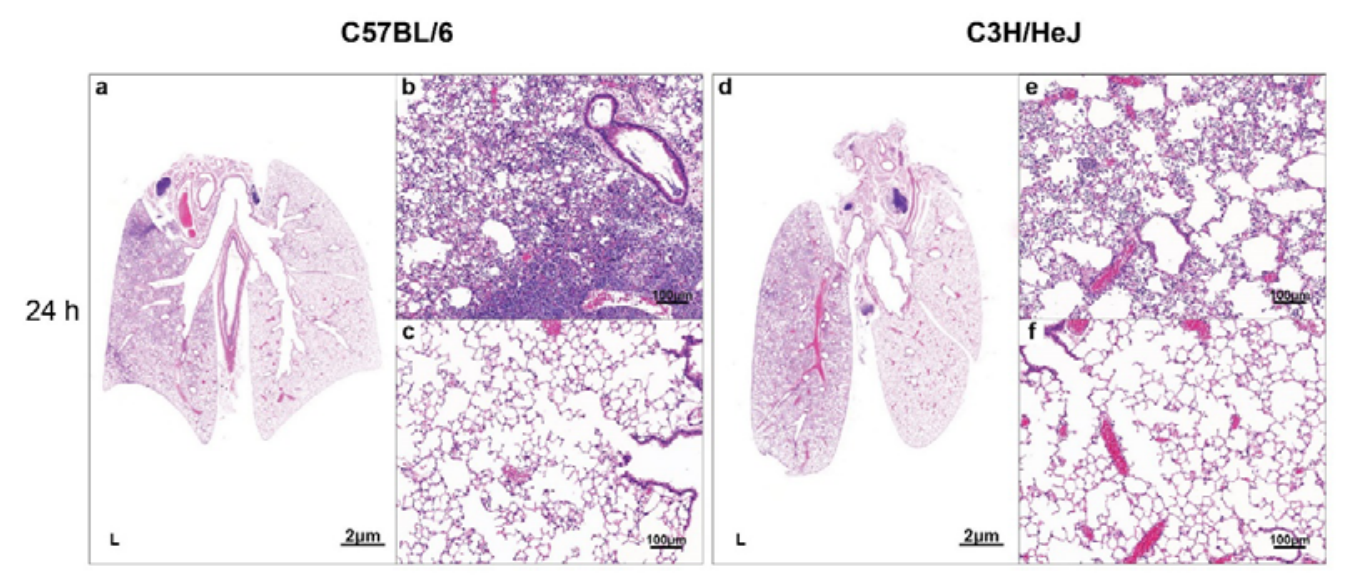

Figure 4 Unilateral live bacteria inoculation: 24 hours after infection, P. aeruginosa didn't induce emphysema in C57BL/6 mice. An abscess full of bacteria at the apex of the left lung formed, but only bronchiectasis-like pathological change $(\mathrm{a}, \mathrm{b})$. On the contrary, P. aeruginosa inoculation induced prominent centriacinar emphysema in $\mathrm{C} 3 \mathrm{H} / \mathrm{HeJ}$ mice (d, e). Control lungs (c, f); H\&E staining; 

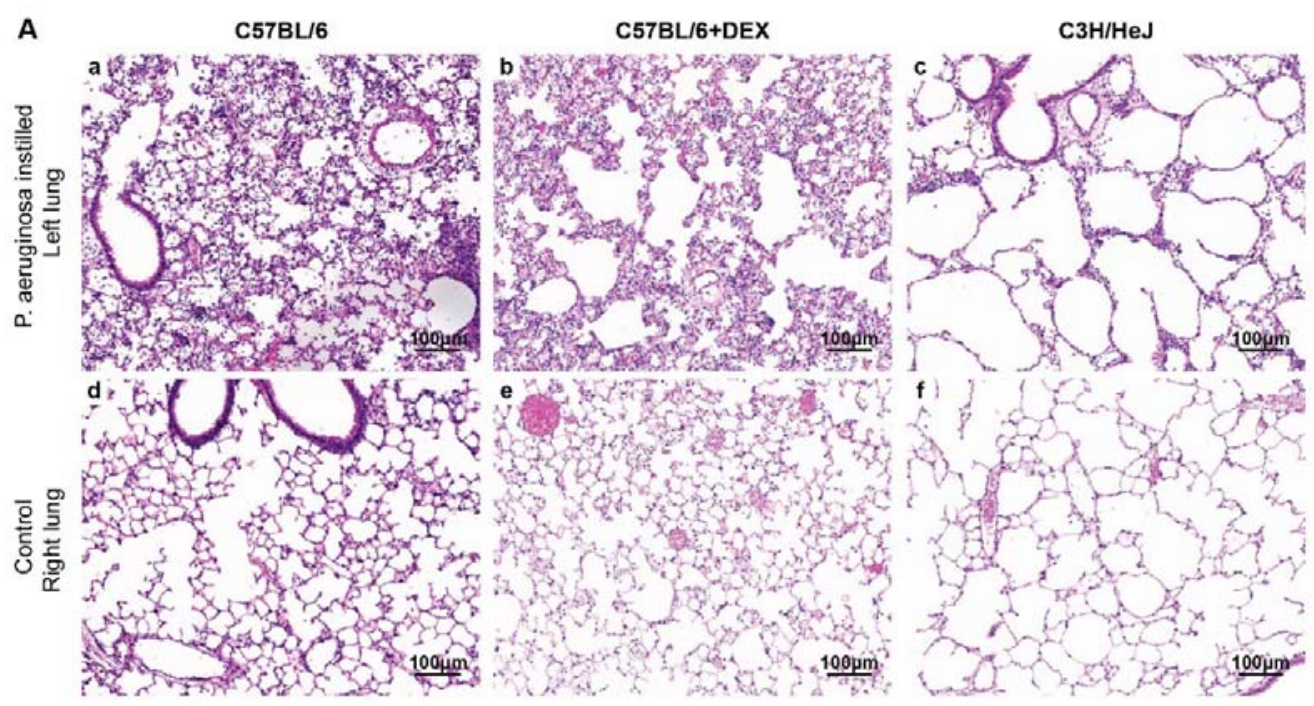

B

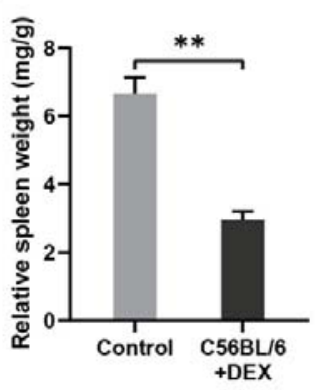

C

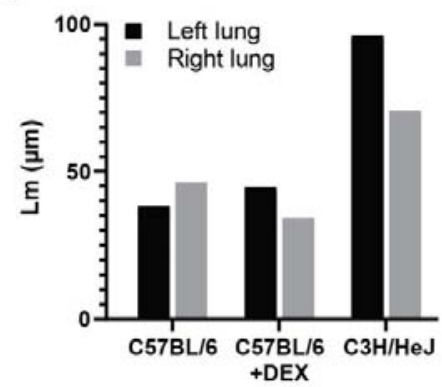

D

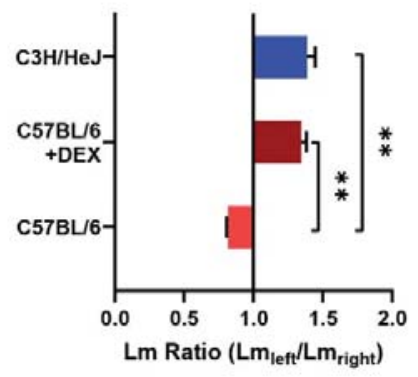

Figure 5 Unilateral live bacteria inoculation in immunosuppressed C57BL/6: (A)

Histology of lung of normal C57BL/6 mice, C57BL/6 + DEX mice, and C3H/HeJ mice, Centriacinar pulmonary emphysema developed in both C57BL/6+DEX mice and $\mathrm{C} 3 \mathrm{H} / \mathrm{HeJ}$ mice, but not in normal C57BL/6 mice. C3HHe/J mice showed the lightest inflammation but most severe emphysema. All mice were inoculated with $30 \mu \mathrm{l}$ of 2 MCF P. aeruginosa and sacrificed after 9 hours; H\&E staining. (B) The decrease of relative spleen weight of C57BL/6 mice treated with DEX shows successful modeling of hypoimmunity. (C) Lm decreased in C57BL/6 mouse. (D) The Lm ratio between different groups shows $P$. aeruginosa infection caused significant airspace enlargement in two immunocompromised mice groups but airspace compression in the normal C57BL/6 group. The data represent the mean \pm SEM of four animals. $* \mathrm{P}<.05 ; * * \mathrm{P}$ $<.01 ; * * * \mathrm{P}<.001$ 